\title{
Bone mineral content and density in healthy subjects and in osteogenesis imperfecta
}

Charles Salt Centre, Robert Jones and Agnes Hunt Hospital, Oswestry, Shropshire SY10 7AG

M W J Davie

M J Haddaway

Correspondence to: Dr Davie.

Accepted 30 November 1993

\begin{abstract}
Lumbar spine bone mineral density in a cross sectional study of healthy subjects increased by 0.012 and $0.016 \mathrm{~g} / \mathrm{cm}^{2} /$ year in boys and girls respectively between 5 and 11 years of age. These rates increased fivefold in girls and threefold in boys between the ages of 11 and 13 years as a result of the bone mineral content increasing more rapidly than the coronal area at this age. By the age of 11 years the girls had $66 \%$ of the coronal area, $61 \%$ of the bone mineral density, and $41 \%$ of the bone mineral content of subjects aged 18-23 years. The ratio (lumbar spine bone mineral content/body weight) was constant in boys aged 6-13 years, but there were significant variations in girls. Femoral neck bone mineral density in both sexes changed little between 6 and 11 years and at 11 years was $69 \%$ of the adult values.

Subjects with osteogenesis imperfecta had a low bone mineral density and bone mineral content for their age and weight. The $\mathrm{z}$ score of bone mineral density at the femoral neck was significantly lower than at the lumbar spine.

In patients with recurrent fractures a low bone mineral density may help in identifying those with osteogenesis imperfecta and assist in their subsequent management.

(Arch Dis Child 1994; 70: 331-334)
\end{abstract}

Bone mineral density measurements in children could be of value in the management of recurrent fractures, osteogenesis imperfecta, hypophosphataemic rickets, and other disorders. ${ }^{1}$ Although dual energy $x$ ray absorptiometry (DXA) is the most widely used form of bone density scanning, there are few reports of its use in children. The relation of bone mineral density with age has variously been plotted as linear ${ }^{2}$ or cubic. ${ }^{3}$ Studies using either dual photon absorptiometry or DXA also suggest an increase in bone mass associated with puberty. ${ }^{14}$ Bone mineral density is related to the Tanner stage of pubertal development, though there is a slightly closer relation with weight. ${ }^{1}$

Measurement of bone mineral density using DXA has been criticised because, unlike quantitative computed tomography, it does not exclude the posterior elements of the vertebrae and because the anteroposterior dimension of the vertebral body (vertebral depth) is not measured. DXA, however, gives low doses of radiation and is more suitable than quantitative computed tomography for use in children.
We investigated the changes in bone mineral density and bone mineral content in children aged from 5 to 13 years. We also used DXA to compare the relation of bone mineral density with weight in healthy children with that in children with osteogenesis imperfecta to identify the value of DXA measurements in such patients.

\section{Subjects and methods}

Normal healthy children were recruited from local schools. Subjects were excluded if they were attending a medical clinic regularly or were known to have a chronic disease. There were 75 girls (aged 5-13 years) and 57 boys (aged 6-13 years), all white. Height and weight were measured in all subjects but ethical permission precluded clinical examination or venepuncture. Permission was obtained from the subjects and their parents/guardians. This protocol was accepted by the Shropshire Health Authority research ethics committee.

Subjects with osteogenesis imperfecta had a mean (SD) age of 11 (3) years. There were three boys and six girls, all of whom had a history of fractures. Each had a family history of the disorder or blue sclerae, or both. All had type 1 osteogenesis imperfecta ${ }^{5}$ and all were usually mobile.

Bone mineral density was measured using a Hologic QDR1000 densitometer (Hologic Inc, Waltham, MA, USA). The second, third, and fourth lumbar vertebrae and the upper end of the left femur were measured. The densities of the lumbar vertebrae were expressed as an average measurement of L2-L4. This technique measures coronal vertebral area and bone mineral density directly and computes the bone mineral content as area multiplied by bone mineral density. ${ }^{6}$ The femoral neck site and Ward's triangle were measured in the left femur. The latter site is defined by the software program as the area with the lowest bone mineral density at the upper end of the femur. Body height was measured with a Harpenden stadiometer (Holtain, Crymmech, UK).

Statistical analysis was undertaken using techniques described in standard texts. ${ }^{78}$ Results are given as mean (SD) unless otherwise stated. Non-parametric tests were used to test significance between groups. As values for bone mineral density and area changed considerably from year to year, values for subjects with osteogenesis imperfecta were converted into $\mathrm{z}$ scores using values for the mean (SD) derived from the appropriate sex and age group of the healthy subjects. Differences between $\mathrm{z}$ scores were tested by the MannWhitney $U$ test. The significance of the 
Table 1 Anthropometric data for healthy girls. Values are mean (SD)

\begin{tabular}{|c|c|c|c|c|c|c|c|c|c|}
\hline & \multicolumn{9}{|l|}{ Age (years) } \\
\hline & $5(n=5)$ & $6(n=4)$ & $7(n=5)$ & $8(n=10)$ & $9(n=7)$ & $10(n=12)$ & $11(n=12)$ & $12(n=14)$ & $13(n=6)$ \\
\hline $\begin{array}{l}\text { Weight }(\mathrm{kg}) \\
\text { Height }(\mathrm{m})\end{array}$ & $\begin{array}{l}17.3(1.30) \\
1.06(0.018)\end{array}$ & $\begin{array}{l}23.9(6.4) \\
1.19(0.05)\end{array}$ & $\begin{array}{l}22.3(0.91) \\
1.21(0.02)\end{array}$ & $\begin{array}{l}24.4(2.60) \\
1.25(0.04)\end{array}$ & $\begin{array}{l}32 \cdot 3(7 \cdot 06) \\
1.33(0 \cdot 07)\end{array}$ & $\begin{array}{l}37 \cdot 5(7 \cdot 2) \\
1 \cdot 41(0 \cdot 6)\end{array}$ & $\begin{array}{l}37.4(8.0) \\
1.44(0.08)\end{array}$ & $\begin{array}{c}45.5(15 \cdot 1) \\
1.49(0.09)\end{array}$ & $\begin{array}{c}46.6(10.3) \\
1.54(0.06)\end{array}$ \\
\hline $\begin{array}{l}\text { Bone mineral content } \\
\text { lumbar spine }(\mathrm{g}) \\
\text { Bone mineral density }\end{array}$ & $9 \cdot 6(1 \cdot 2)$ & $12 \cdot 1(2 \cdot 0)$ & $14 \cdot 3(1 \cdot 2)$ & $14 \cdot 1(1 \cdot 9)$ & $15 \cdot 3(3 \cdot 4)$ & $18 \cdot 4(4 \cdot 1)$ & $19 \cdot 2(4 \cdot 9)$ & $25.4(8.5)$ & $29.9(6 \cdot 1)$ \\
\hline $\begin{array}{l}\text { lumbar spine }\left(\mathrm{g} / \mathrm{cm}^{2}\right) \\
\text { Bone mineral density }\end{array}$ & $0.535(0.04)$ & $0.593(0.029)$ & $0.651(0.032)$ & $0.636(0.048)$ & $0.590(0.048)$ & $0.670(0.073)$ & $0.657(0.085)$ & $0.764(0.111)$ & $0.833(0.117)$ \\
\hline $\begin{array}{l}\text { Ward's triangle }\left(\mathrm{g} / \mathrm{cm}^{2}\right) \\
\text { Bone mineral density }\end{array}$ & $0.480(0.028)$ & $0.520(0.04)$ & $0.545(0.043)$ & $0.544(0.053)$ & $0.540(0.067)$ & $0.525(0.064)$ & $0.529(0.085)$ & $0.617(0.100)$ & $0.633(0.109)$ \\
\hline $\begin{array}{l}\text { femoral neck }\left(\mathrm{g} / \mathrm{cm}^{2}\right) \\
\text { Lumbar spine bone mineral }\end{array}$ & $0.540(0.025)$ & $0.605(0.029)$ & $0.611(0.031)$ & $0.625(0.051)$ & $0.635(0.055)$ & $0.646(0.078)$ & $0.636(0.080)$ & $0.740(0.100)$ & $0.769(0.108)$ \\
\hline content/weight $(\mathrm{g} / \mathrm{kg})$ & $0.557(0.066)$ & $0.517(0.062)$ & $0.642(0.051)$ & $0.580(0.054)$ & $0.476(0.062)$ & $0.496(0.092)$ & $0.514(0.070)$ & $0.564(0.076)$ & $0.651(0.096)$ \\
\hline
\end{tabular}

Table 2 Anthropometric data for healthy boys. Values are mean (SD)

\begin{tabular}{|c|c|c|c|c|c|c|c|c|}
\hline & \multicolumn{8}{|l|}{ Age (years) } \\
\hline & $6(n=6)$ & $7(n=4)$ & $8(n=6)$ & $9(n=5)$ & $10(n=10)$ & $11(n=12)$ & $12(n=6)$ & $13(n=8)$ \\
\hline $\begin{array}{l}\text { Weight }(\mathrm{kg}) \\
\text { Height }(\mathrm{m}) \\
\text { Bone mineral content }\end{array}$ & $\begin{array}{l}22 \cdot 8(3 \cdot 8) \\
1 \cdot 21(0 \cdot 05)\end{array}$ & $\begin{array}{l}24 \cdot 1(1 \cdot 9) \\
1 \cdot 23(0 \cdot 06)\end{array}$ & $\begin{array}{l}27 \cdot 7(2 \cdot 9) \\
1 \cdot 31(0 \cdot 09)\end{array}$ & $\begin{array}{l}30.8(2.9) \\
1.36(0.06)\end{array}$ & $\begin{array}{l}34 \cdot 8(5 \cdot 7) \\
1 \cdot 40(0 \cdot 05)\end{array}$ & $\begin{array}{l}33 \cdot 7(4 \cdot 1) \\
1 \cdot 41(0.053)\end{array}$ & $\begin{array}{l}42 \cdot 7(8.0) \\
1.53(0.07)\end{array}$ & $\begin{array}{c}41 \cdot 6(4 \cdot 9) \\
1.57(0.09)\end{array}$ \\
\hline $\begin{array}{l}\text { lumbar spine (g) } \\
\text { Bone mineral density }\end{array}$ & $13.5(1 \cdot 2)$ & $14 \cdot 1(2 \cdot 6)$ & $14 \cdot 4(2 \cdot 3)$ & $17 \cdot 0(4 \cdot 8)$ & $18 \cdot 4(2 \cdot 2)$ & $17 \cdot 3(2 \cdot 9)$ & $23 \cdot 8(6 \cdot 1)$ & $25 \cdot 3(4 \cdot 9)$ \\
\hline lumbar spine $\left(g / \mathrm{cm}^{2}\right)$ & $0.574(0.043)$ & $0.600(0.062)$ & $0.601(0.046)$ & $0.619(0.097)$ & $0.643(0.059)$ & $0.625(0.065)$ & $0.692(0.097)$ & $0.704(0.083)$ \\
\hline $\begin{array}{l}\text { Bone mineral density } \\
\text { Ward's triangle }\left(\mathrm{g} / \mathrm{cm}^{2}\right) \\
\text { Bone mineral density }\end{array}$ & $0.571(0.033)$ & $0.601(0.069)$ & $0.584(0.100)$ & $0.620(0.119)$ & $0.605(0.074)$ & $0.573(0.064)$ & $0.654(0.071)$ & $0.618(0.063)$ \\
\hline $\begin{array}{l}\text { femoral neck }\left(\mathrm{g} / \mathrm{cm}^{2}\right) \\
\text { Lumbar spine bone mineral }\end{array}$ & $0.624(0.047)$ & $0.672(0.053)$ & $0.653(0.059)$ & $0.702(0.080)$ & $0.698(0.067)$ & $0.697(0.052)$ & $0.746(0.049)$ & $0.734(0.036)$ \\
\hline content/weight $(\mathbf{g} / \mathbf{k g})$ & $0.602(0.094)$ & $0.583(0.062)$ & $0.524(0.053)$ & $0.551(0.135)$ & $0.538(0.075)$ & $0.515(0.066)$ & $0.564(0.127)$ & $0.605(0.061)$ \\
\hline
\end{tabular}

deviation from the expected frequencies in a normal distribution was tested by the Kolmogorov-Smirnov test.

\section{Results}

Tables 1 and 2 give the bone mineral measurements for healthy subjects. In the lumbar spine the mean bone mineral density in girls increased only slightly $\left(0.016 \mathrm{~g} / \mathrm{cm}^{2} /\right.$ year; $r=0.40$ ) between 5 and 11 years of age. After 11 years the rate increased to $0.089 \mathrm{~g} / \mathrm{cm}^{2} /$ year $(r=0.53)$. The increase in bone mineral density obscured the difference in the changes of bone mineral content and area with age. The average lumbar bone mineral content in girls increased by $1.54 \mathrm{~g} /$ year from 5 to 11 years $(r=0.67)$ and by $5.6 \mathrm{~g} /$ year from 11 to 13 years $(r=0.53)$. Although the rate of increase of bone mineral content more than trebled, the rate of increase of the coronal area only doubled from 1.8 to $3.6 \mathrm{~cm}^{2} /$ year over the same time intervals. Figure 1 gives the relations of bone mineral content, bone mineral density, and area with age in girls.

Lumbar bone mineral density in boys increased by $0.012 \mathrm{~g} / \mathrm{cm}^{2} /$ year from 6 to 11 years $(r=0.30)$ and by $0.048 \mathrm{~g} / \mathrm{cm}^{2} /$ year between 11 and 13 years $(r=0.50)$. Lumbar bone mineral content increased by $0.96 \mathrm{~g} /$ year up to the age of 11 years $(r=0.51)$ and by 3.93 g/year from 11 to 13 years $(r=0 \cdot 64)$. The rates of change were not significantly different from those in girls.

In healthy children the bone mineral density in the lumbar spine correlated with weight with no difference between the sexes for subjects over the age ranges investigated $(r=0.74)$ (fig 2 ). The intercept for bone mineral density was $0.43 \mathrm{~g} / \mathrm{cm}^{2}$. The lumbar spine bone mineral content also correlated with body weight, with an intercept of $0.9 \mathrm{~g}$ in girls and $0.6 \mathrm{~g}$ in boys (difference in intercepts, $p=N S$ ).

The amount of mineral in the lumbar spine (L2-L4) as a proportion of body weight between 5 and 13 years of age was not constant in girls. There were peaks of $6.42 \times 10^{-2 \%}$ at 7 years and $6.51 \times 10^{-2 \%}$ at 13 years, and a nadir of $4.76 \times 10^{-2 \%} \%$ at 9 years, the differences being greater than would be expected by chance at the $1 \%$ level (Kruskal-Wallis test). No significant difference was found in boys (mean (SD) $5.55(0 \cdot 84) \times 10^{-2 \%} \%$ ).

In girls the bone mineral density in the femoral neck increased by $0.016 \mathrm{~g} / \mathrm{cm}^{2} /$ year between 5 and 11 years $(r=0.48)$ and by 0.075 $\mathrm{g} / \mathrm{cm}^{2} /$ year between 11 and 13 years $(r=0.54)$. In boys the increase $\left(\mathrm{g} / \mathrm{cm}^{2} /\right.$ year) was 0.017

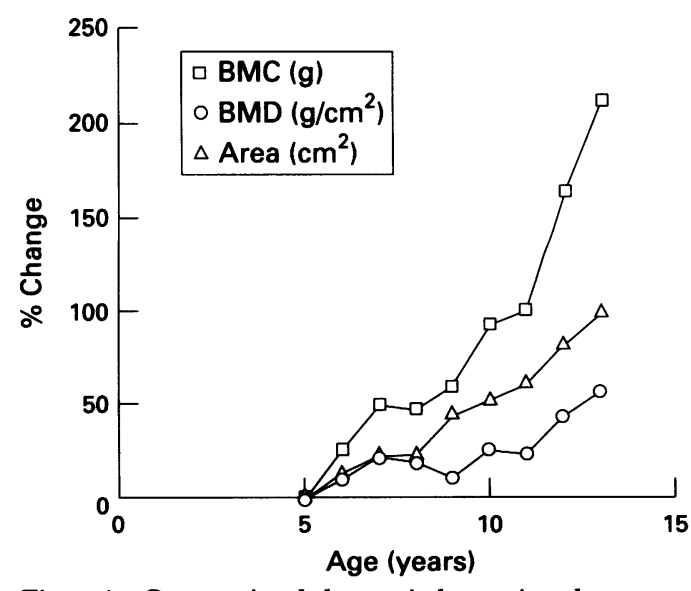

Figure 1 Cross sectional changes in bone mineral content (BMC), bone mineral density (BMD), and area in the lumbar spine of girls, expressed as the percentage change from values at 5 years. Bone mineral density does not change greatly between 5 and 11 years, whereas the BMC increases by $100 \%$. 


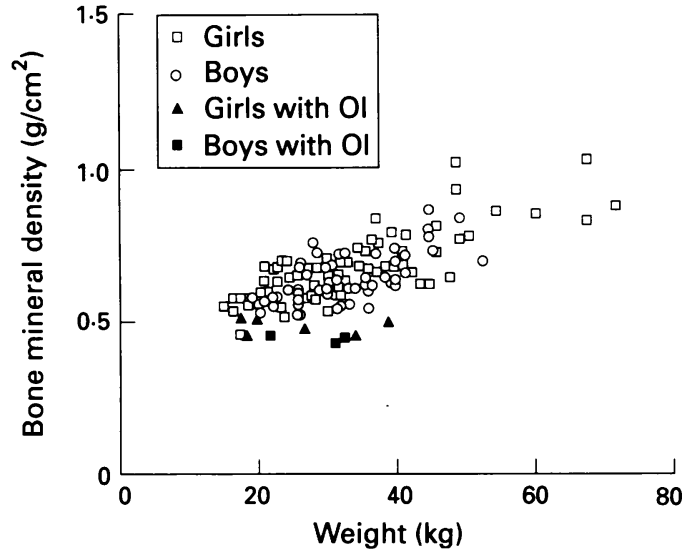

Figure 2 Bone mineral density plotted as a function of weight for healthy boys and girls. The regression equation is $y=0.43+0.0067 x(r=0.74)$. Subjects with osteogenesis imperfecta (OI) have a low bone density for their weight.

between 6 and 11 years $(r=0.40)$ and 0.019 $(r=0.44)$ between 11 and 13 years. The relation between bone mineral density and age at Ward's triangle was not as close as at the femoral neck.

Subjects with osteogenesis imperfecta had had a mean of 0.65 fractures each year (range $0 \cdot 28-0.91$; table 3 ) over their lifetime. The most frequent fracture sites were the tibia (20 fractures), followed by the humerus (11), radius (10), femur (nine), and ulna (seven). We compared values of bone mineral density in the spine and femur, and of the bone mineral content and area in the spine in subjects with osteogenesis imperfecta with those in healthy subjects by converting the data for subjects with osteogenesis imperfecta into $\mathrm{z}$ scores (see under methods). Compared with values in healthy normal subjects, vertebral area $(p<0.05)$ and vertebral bone mineral density and bone mineral content $(p<0.01)$ were all low. The vertebral bone mineral density $\mathrm{z}$ score $(-2 \cdot 52$ $(0.49))$ was significantly lower than vertebral area $\mathrm{z}$ score $(-1.14(0.49))(\mathrm{p}<0.02$; MannWhitney $U$ test). Bone mineral density $\mathrm{z}$ scores were lower in the femoral neck than in the lumbar spine $(p<0.05)$. In relation to body weight both bone mineral content $(p<0.05)$ and bone mineral density $(p<0.05)$ were low in the subjects with osteogenesis imperfecta (fig 2 ; table 3).

\section{Discussion}

The pattern of increase in bone mineral density in the lumbar spine, with an increase to 7 years followed by a plateau to 11 years and thereafter an acceleration in the rate of increase, more closely followed the cubic pattern ${ }^{13}$ than a linear relation. ${ }^{2}$ Mean values for each age group were similar to those previously reported. ${ }^{13}$

The bone mineral content, however, measures the total mineral present and provides a measure of mineral accumulation at particular sites. In this study the spinal bone mineral content increased slowly between 5 and 11 years at a rate of $1.54 \mathrm{~g} /$ year in girls, though in this sex the bone mineral content in the lumbar vertebrae as a proportion of body weight actually decreased between 5 and 9 years. This might arise as a result of bone being laid down at other sites. There was, however, a good correlation between the total lumbar and total femoral bone mineral content in girls aged 5-11 years $(r=0.92$; slope $=0.99)$, suggesting that accumulation at these two sites was continuing at a similar rate. Tissue other than bone, such as fat, may have been accumulating preferentially at other sites. The minimal increase of lumbar spine bone mineral density between these ages in girls is similar to the lack of change of bone density measured by computed tomography over the same age group. ${ }^{9-12}$

The changes in vertebral bone mineral occurring at the age of 11-13 years and thereafter are considerable. The rate of increase of bone mineral content increased threefold and bone mineral density fivefold in girls aged 11-13 years compared with the change between 5 and 11 years. The bone mineral density increase measured by DXA $(12.2 \%$ /year) was itself higher than the rate of increase (3.1\%/year) calculated from data obtained by computed tomography. ${ }^{911} 12$ To achieve the values measured in our unit for bone mineral density ${ }^{13}$ or bone mineral content and area (Haddaway $M \mathrm{~J}$, Davie $\mathrm{M}$ W J, unpublished data) for women aged 18-23 years, girls aged 11 years will increase their bone mineral density by $62 \%$, their vertebral area by $44 \%$, and their bone mineral content by $135 \%$. The discrepancies between increases in bone mineral density found by computed tomography and by DXA and between the changes of bone mineral density and bone mineral content measured by DXA could result from a disproportionate increase in the anteroposterior dimension of the vertebral body, or in greater mineralisation of the posterior vertebral elements. Furthermore, the

Table 3 Anthropometric data for patients with osteogenesis imperfecta

\begin{tabular}{|c|c|c|c|c|c|c|c|c|c|c|c|c|c|c|c|c|}
\hline \multirow[b]{2}{*}{$\begin{array}{l}\text { Patient } \\
\text { No }\end{array}$} & \multirow[b]{2}{*}{ Sex } & \multirow[b]{2}{*}{$\begin{array}{l}\text { Age } \\
\text { (years) }\end{array}$} & \multirow{2}{*}{$\begin{array}{l}\text { No of } \\
\text { fractures/ } \\
\text { year }\end{array}$} & \multirow[b]{2}{*}{$\begin{array}{l}\text { Weight } \\
(\mathrm{kg})\end{array}$} & \multirow[b]{2}{*}{$\begin{array}{l}\text { Weight } \\
z \text { score }\end{array}$} & \multirow[b]{2}{*}{$\begin{array}{l}\text { Height } \\
(m)\end{array}$} & \multirow{2}{*}{$\begin{array}{l}\text { Weight } \\
\text { height } \\
\left(\mathrm{kg} / \mathrm{m}^{2}\right)\end{array}$} & \multirow{2}{*}{$\begin{array}{l}\text { Bone } \\
\text { mineral } \\
\text { content } \\
\text { spine }(g)\end{array}$} & \multirow{2}{*}{$\begin{array}{l}\text { Bone } \\
\text { mineral } \\
\text { content } \\
\text { weight } \\
(\mathrm{g} / \mathrm{kg})\end{array}$} & \multirow{2}{*}{$\begin{array}{l}\text { Bone } \\
\text { mineral } \\
\text { content/ } \\
\text { weight } \\
z \text { score }\end{array}$} & \multicolumn{3}{|c|}{ Bone density $\left(\mathrm{g} / \mathrm{cm}^{2}\right)$} & \multicolumn{3}{|c|}{ Bone mineral density $z$ score } \\
\hline & & & & & & & & & & & $\begin{array}{l}\text { Lumbar } \\
\text { spine }\end{array}$ & $\begin{array}{l}\text { Femoral } \\
\text { neck }\end{array}$ & $\begin{array}{l}\text { Ward's } \\
\text { triangle }\end{array}$ & $\begin{array}{l}\text { Lumbar } \\
\text { spine }\end{array}$ & $\begin{array}{l}\text { Femoral } \\
\text { neck }\end{array}$ & $\begin{array}{l}\text { Ward's } \\
\text { triangle }\end{array}$ \\
\hline $\begin{array}{l}1 \\
2 \\
3 \\
4 \\
5 \\
6 \\
7 \\
8 \\
9\end{array}$ & $\begin{array}{l}F \\
F \\
F \\
F \\
F \\
F \\
M \\
M \\
M\end{array}$ & $\begin{array}{r}10 \cdot 1 \\
12.3 \\
6.0 \\
10 \cdot 8 \\
5.7 \\
12.6 \\
11.5 \\
11.5 \\
7.6\end{array}$ & $\begin{array}{l}0.91 \\
0.82 \\
0.28 \\
0.46 \\
0.87 \\
0.4 \\
0.7 \\
0.69 \\
0.69\end{array}$ & $\begin{array}{l}27 \cdot 5 \\
40 \cdot 0 \\
18 \cdot 1 \\
35 \cdot 0 \\
18 \cdot 8 \\
40 \cdot 5 \\
33 \cdot 5 \\
32 \cdot 0 \\
22 \cdot 5\end{array}$ & $\begin{array}{r}-1.389 \\
-0.364 \\
-0.906 \\
-0.347 \\
1.154 \\
-0.331 \\
-0.049 \\
-0.415 \\
-0.842\end{array}$ & $\begin{array}{l}1.31 \\
1.41 \\
1.13 \\
1.29 \\
1.19 \\
1.44 \\
1.26 \\
1.27 \\
1.12\end{array}$ & $\begin{array}{l}16 \cdot 0 \\
20 \cdot 1 \\
14 \cdot 2 \\
21 \cdot 0 \\
13 \cdot 3 \\
19 \cdot 5 \\
21 \cdot 1 \\
19 \cdot 8 \\
17 \cdot 9\end{array}$ & $\begin{array}{r}11 \cdot 13 \\
11.59 \\
8 \cdot 46 \\
9 \cdot 59 \\
8 \cdot 75 \\
16 \cdot 19 \\
9 \cdot 65 \\
9 \cdot 46 \\
9.05\end{array}$ & $\begin{array}{l}0 \cdot 405 \\
0 \cdot 29 \\
0 \cdot 467 \\
0 \cdot 274 \\
0 \cdot 465 \\
0 \cdot 399 \\
0 \cdot 288 \\
0 \cdot 296 \\
0 \cdot 402\end{array}$ & $\begin{array}{l}-0.992 \\
-3.609 \\
-0.8 \\
-2.413 \\
-1.387 \\
-2.161 \\
-3.438 \\
-3.324 \\
-2.916\end{array}$ & $\begin{array}{l}0.473 \\
0.49 \\
0.505 \\
0 \cdot 447 \\
0.454 \\
0.572 \\
0 \cdot 449 \\
0 \cdot 426 \\
0.448\end{array}$ & $\begin{array}{l}0.508 \\
0.308 \\
0.485 \\
0.488 \\
0.475 \\
0.575 \\
0.47 \\
0.43 \\
0.465\end{array}$ & $\begin{array}{l}0.39 \\
0 \cdot 196 \\
0.337 \\
0 \cdot 265 \\
0.413 \\
0 \cdot 61 \\
0 \cdot 35 \\
0 \cdot 293 \\
0 \cdot 279\end{array}$ & $\begin{array}{l}-2.70 \\
-2.47 \\
-3.03 \\
-3.05 \\
-2.03 \\
-1.73 \\
-2.71 \\
-3.06 \\
-2.45\end{array}$ & $\begin{array}{l}-1 \cdot 77 \\
-4 \cdot 32 \\
-4 \cdot 14 \\
-4 \cdot 03 \\
-2 \cdot 6 \\
-1 \cdot 65 \\
-4.37 \\
-6.03 \\
-3.91\end{array}$ & $\begin{array}{l}-2 \cdot 11 \\
-4 \cdot 21 \\
-4 \cdot 58 \\
-4 \cdot 06 \\
-2 \cdot 39 \\
-0.07 \\
-3 \cdot 48 \\
-4 \cdot 38 \\
-1 \cdot 77\end{array}$ \\
\hline
\end{tabular}


appearance at puberty of seven ossification centres in the posterior part of the lumbar vertebral body at the spinous processes, mammillary bodies, and cranial and caudal surfaces of the vertebra ${ }^{14}$ could also lead to a considerable increase of mineral, which would disproportionately increase the bone mineral density measured by DXA.

Values for bone mineral density at the femoral neck generally changed in a similar fashion with age as at the spine. At 11 years, however, the bone mineral density in the femoral neck expressed as a proportion of the bone mineral density in the femoral neck of subjects aged 18-23 years was $69 \cdot 8(0 \cdot 8) \%$. This was higher than the value of $61.2(0.9) \%$ in the lumbar spine $(p<0.01$; Wilcoxon paired ranks). The fact that a greater proportion of the adult bone mineral density has been achieved by 11 years of age in girls may indicate that the prepubertal accumulation of bone mineral density is relatively more important at the femur than at the spine.

Subjects with osteogenesis imperfecta had lower $\mathrm{z}$ scores for body weight (table 3 ). Height was more severely affected, but only three subjects had a height $\mathrm{z}$ score of less than $-2 \cdot 00$. The relative sparing of height deficiency suggests that repeated fractures are not as serious a handicap to growth as might be expected. In contrast, the bone mineral density was extremely low in all subjects, with the long bone (femur) being more severely affected (in terms of deviation from the mean) than the axial skeleton. At the spine the deficiency of bone mineral is partially attributable to the vertebrae having a lower coronal cross sectional area. As bone mineral density, which is independently measured, is even lower than the mean values, bone mineral within the vertebrae is also likely to be deficient. Whether the onset of puberty can overcome one or both of these deficiencies will require careful longitudinal study.

These data suggest that DXA might be of value in the management of fractures in childhood. In children with recurrent fractures a low bone density might help to define a cause and possibly detect mild osteogenesis imperfecta. These data suggest that the femur might be a more valuable site to measure than the spine. Further work is required, however, to examine the bone mineral density at other sites such as the tibiae, humeri and wrists, which are the most common sites of fracture in our patients.

Measurements of bone density in children by DXA could also provide useful data to help with the management of patients with osteogenesis imperfecta. Patients have been treated with bisphosphonates, ${ }^{15}$ and it would be useful to be able to measure changes in bone mineral to ensure that a response was occurring and to avoid overtreatment that might hinder height gain.

1 Southard RN, Morris JD, Mahan JD, et al. Bone mass in healthy children: measurement with quantitative DXA Radiology 1991; 179: 735-8.

2 Kroger H, Kotaniemi P, Vaino P, Alhava E. Bone densitometry of the spine and femur in children by dual energy $x$-ray absorptiometry. Bone Miner 1992; 17: 75-85.

3 Glastre C, Braillon P, David L, Cochat P, Meunier PJ, Delmas PD. Measurement of bone mineral content of the lumbar spine by duel energy $\mathrm{X}$-ray absorptiometry in normal children: correlations with growth parameters. f Clin Endocrinol Metab 1990; 70: 1330-3.

4 De Schepper J, Derde MP, Van den Broeck M, Piepz A, Jonckheer MH. Normative data for lumbar spine bone Jonckheer MH. Normative data for lumbar spine bone mineral content in children: influence of age, height,

weight and pubertal stage. $\mathcal{F}$ Nucl Med $1991 ; 32: 216-20$.
Beighton P. Inherited disorders of the skeleton. London: Churchill Livingstone, 1988.

6 Blake GM, Tong CM, Fogelman I. Intersite comparison of the Hologic QDR-1000 dual energy X-ray bone densitometer. Br $\mathcal{F}$ Radiol 1991; 64: 440-6.

7 Snedecor GW, Cochran WG. Statistical methods. Iowa: Iowa State University Press, 1980.

8 Siegel S. Non-parametric statistics. New York: McGraw-Hill, 1956.

9 Gilsanz V, Roe TL, Mora S, Costin G, Goodman WG. Changes in vertebral bone density in black girls and white Changes in vertebral bone density in black girls and white girls during childhe

10 Cann CE, Genant HK, Kolb FO, Ettinger B. Quantitative computed tomography for prediction of vertebral fracture risk. Bone 1985; 6: 1-7.

11 Gilsanz V, Gibbens DT, Carlson M, Boechat MI, Cann CE, Schulz EE. Peak trabecular vertebral density: a comparison of adolescent and adult females. Calcif Tissue Int 1988; 43: 260-2.

12 Gilsanz V, Gibbens DT, Roe TF, et al. Vertebral bone density in children: effect of puberty. Radiology 1988; 166: 847-50.

13 Haddaway MJ, Davie MWJ, McCall IW. Bone mineral density in healthy normal women and reproducibility of measurements in spine and hip using dual-energy $X$-ray absorptiometry. Br $\mathcal{F}$ Radiol 1992; 65: 213-7.

14 Williams PL, Warwick R, Dyson M, Bannister LH. Gray's anatomy. London: Churchill Livingstone, 1989

15 Devogelaer JP, Nagant de Deuxchaisnes C, Malghem J, Maldague B. Cyclical intermittent therapy with APD in child with osteogenesis imperfecta: a 3-year follow-up of 7 cycles. Evidence of fading away of the oldest radio-opaque bands. In: Christiansen C, Overgaard K, eds. Third International Symposium on Osteoporosis. Copenhagen, International 1990: 1515-7. 